\title{
University Educational Service Delivery Strategy In A Changing World: Implications For Ethical Values And Leadership Integrity In Nigeria
}

\author{
D. I. Akintayo, (Email: pastordayoakin@yahoo.com), Olabisi Onabanjo University, Nigeria
}

\begin{abstract}
This paper examined university educational service delivery strategy in a changing world as it affects ethical values and leadership integrity in Nigeria. This was for the purpose of determining appropriate strategies for improving the quality of service delivery system in Nigerian universities. The paper submits that the quality and quantity of educational services has considerably been improved in relation to internal efficiency of resources. Moreso, the problem of access to education has become a significant phenomenon with its deleterious effect on labour market supply. The university education has also become more relevant to manpower training and development. However, the paper established that the high level of moral decadence among the students as well as the leaders has affected the quality of education in Nigeria. The deplorable condition of Nigerian universities need be improved upon by all the stakeholders. Also, resource allocation and utilization towards quality assurance in Nigerian education system need be properly considered for financial and moral supports by the government and private organizations in Nigeria.
\end{abstract}

\section{INTRODUCTION}

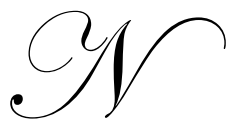

igerian educational system has undergone a great deal of change in the past forty-four years since independence. University education has evolved its own pattern, being an admixture of the British traditional university system and the Nigerian university dynamic system. Nigerian university has established a reasonably solid foundation in the humanities, natural sciences and machine, applied sciences and the technologies. The curricula have been revised to take account of the expanding knowledge about the world around us and to which Nigeria must contribute its quota (Solomon, 2001).

Unprecedent expansion of Nigerian education system over the years has placed heavy demands on the management of university education. Despite efforts expanded towards coping with these demands, the university education is still lagging behind the growth in size and complexity of our educational system. In crease in population at the primary and secondary levels of education spells out increase in the higher institution, comprising Universities, Polytechnics, Colleges of Education and Technology. Thus, the education systems, more especially the universities have been too much confirmed to quantitative expansion trading in the complementary development in educational quality (Alumanah, 2001).

However, measures to promote higher education and improve the quality of university education to meet the challenges of a constantly changing environment are often constrained by under-funding and inadequate financial resources (Akinkugbe, 2001, Nwaka, 2000, Ajani, 1999, and Banjo, 1999). The expansion of the universities in Nigeria, therefore without mankind funds has brought about dearth of other resources and facilities, for instance, unavailable and run-down physical infrastructure, inadequate laboratories and ill-equipped libraries. 
The next contributory factors to the decline to the university education system are leadership indiscipline and subversion of autonomy, which lead to the erosion of academic freedom (Akinkugbe, 2001, Banjo, 1999, Alumanah, 2001 and Ologunde, 2003). These had eroded the powers of the universities and brought about lack of proper governance at both the societal and institutional levels.

Education in human capital theory has always been seen to have an important role in furthering economic and social development. It is a strong catalyst of equity, and advancement. The education system particularly university education needs constant review and reform for sustainable human capital formation. Ajayi (1999) and Birma (1998) contend that Nigerian educational system has gone comatose and it in dire need of emergency surgical operation in order to create room for effective educational service delivery.

In Nigeria, university leadership construed either in terms of an individual leader or an organizational function (Middlehurst, 1995) or even as an institutional structure or a model for human action, has largely failed to promote the fundamental educational goals of producing good and useful citizens ensuring greater efficiency and productivity, and promoting attitude conducive to tolerance, justice, equity, harmony in society. Asobie (1998) has rightly noted that leadership is different from the mere exercise of power or the use of legitimate force. One can attain the status or position of professor in academic discipline and yet be incapable of providing academic leadership. This situation can become a threat to attainment of educational goals in the nation (Oderinde.2005).

A recent report by the Committee for Defence of Human Rights (CDHR) (2001) says that 'all round our tertiary institutions, injustice in various forms stares us in the face. All we do is to watch others in positions of authority and responsibility more away from honesty and accountability to dishonesty and unbridled fraudulence. Thus, the failure of leadership in the Nigerian universities is seen in the ethical and leadership indiscipline displayed by a crop of university administrators who have emerged on the landscape of university governance since the 1970s to the meaning of university administrator which is in need of clarification. According to Taiwo (2004), this situation has therefore led to corruption, injustice, violence, examination malpractices, moral decadence and general apathy and anomie within the Nigerian university system.

Against the foregoing, this paper assesses the quantity and quality of education, the extent of moral decadence and leadership involvement in the university system operation. Also, the paper examines the nature and functions of the university, problems of access to university education and implications for ethical and leadership integrity with particular reference to Nigerian context.

\section{UNIVERSITY EDUCATION AND MANPOWER DEVELOPMENT}

The National Policy on Education (2002) shapes the focus of Nigerian university towards achieving the following objectives: the acquisition, development and inculcation of the proper value orientation for the survival of the individual and society; development of the intellectual capacities of individuals to understand and appreciate their environments, acquisition of both physical and intellectual skills which will enable individual to develop into useful members of the community, and the acquisition of an objective view of the national and international environments. University education is thus meant to be development-oriented, whether in respect of the society or the individual and whether in physical or psychological dimensions.

Clement (2004) asserts that over the years, the university has meant different things to different people yet; it has not detracted from the fact that it has a core meaning and set of functions as understood by scholars. However, the primary function of university is manpower development. Hannah (1998) and Ujomu (2001) contend that universities are enterprises that produce and distribute a public good, which is knowledge. In the same vein, Salter (1983) argues that production of knowledge is the major focus of universities and that production of knowledge has always linked up with teaching and research. Apart from teaching and research universities also grant academic degrees (Dohn, 1970). 
The National Policy on Education (1989) admits that the higher education should, among other things aim

at:

The acquisition, development and inculcation of the proper knowledge, skills and values - orientation for the survival of individual and society, the acquisition of both physical and intellectual skills which will enable individuals to develop into useful members of the community.

In essence, the philosophy of education in Nigeria holds that university teaching should seek to inculcate a spirit of community in the students. It is however, being observed that this spirit of community, which is lacking in most universities, is required both within and among the different levels of staff in the university, as well as, between the students and staff. The failure of National Policy on Education is clearly seen in the fact that, over the years, acts such as victimization of staff and students, examination malpractices, cultism, sexual harassment tyranny, high handedness, and corruption in the university system have grown to unprecedented proportions.

Furthermore, besides production of knowledge and skills impartation, the university serves other important purpose in the society. Plessner (1992) asserts that the modern university makes possible the acquisition of independence by individuals. It promotes the awakening and consolidation of critical awareness of independence and creative thinking of the ability to go beyond what is already known. Similarly, Rohrs (1989) holds that the university strives towards intellectual freedom, by posing fundamental questions and isolating itself from social pressure in an environment of meditative calm. He posits further that:

The essence of university education is manpower development, which takes place in the living confrontation with knowledge; professional competence and a civil sense of responsibility is merely the product of having received university education.

Meanwhile, the important point to note is that though the university is a centre for the creation, processing and dispersal of knowledge, it also instills values and good traits of character in individuals so that they can fulfill their social roles more properly. This supports the assertion of Akinpelu (2001) who posits that universities are the seed-beds of liberty, of humanity, emancipation, freedom from poverty and of the charity of thought and deed.

Reflecting on the role of university in human resource development, it could be observed that, the university, right from its inception, has neither inculcated a spirit of community and emancipation in the students, nor has it imbued this value system in the staff. There remains a high incidence of political and ethnic conflicts among the staff. There are conflictual interests and goals between university administration and various academic and non-academic unions. There are conflicts between factions of the students' union and organized students fraternity or cult groups. These are evidences that the much needed ethical values, such as, dialogue, fraternity, peace and discipline are lacking in most of the university systems across the nations (Geoffrey, 2005).

\section{DEMOCRATIZATION OF UNIVERSITY SYSTEM IN NIGERIA}

Democracy denotes self-government and sovereign power to determine and control resources for internal efficiency within university system. In practice, Nigerian universities have been cut off from direct communication with the government. Although, the objective of establishing the National Universities Commission (NUC) was to accord the universities autonomy, academics now see the NUC as the interventionist arm of government for oppression (Omoregie, 1994). Besides, it has been argued that the distance between the government and the universities represented by the Ministry of Education and the National Universities Commission has seriously blurred the understanding, which the government of Nigeria used to have for understanding the needs of the universities during the 1960s and early 1970s. As a result of the foregoing, funds have dwindled resulting in the state of ineffectiveness in the country's university system.

The issue of autonomy acquires a wider dimension in recent times especially among students of Federal Universities when the President Obasanjo administration made a pronouncement on it that full autonomy would be granted to universities. In fact, soon after the Federal Government pronouncement, on the matter, fear gripped the 
university communities as they perceived the Federal Government's intention as dubious. The issue was subjected to several interpretations by the general public to the extent that students across the country staged peaceful demonstrations at the various university campuses in the federation to protest their rejection of the Federal Government's intention.

To the students, autonomy means quite a different thing. It means government handing off the funding of higher institutions and increase in their school fees. Based on this assumption, students groups under various factions have risen to protest the autonomy. For instance, some students under the umbrella of relational Union of Northern Students raised an alarm that the so-called autonomy will sound the death knell for education in the region. The body further called on all Northern Students to join any protest against university autonomy in their various universities (Abdullahi, 2001). Also, the students of University of Benin, Benin and Bayero University, Kano, staged peaceful demonstration against the government granting university autonomy. Towards this end, they sent protest letters to the federal government indicating that university autonomy is bound to put a final nail in the coffin of ivory towers in Nigeria, which they said was already tottering under the weight of inadequate funding and inconsistent development policies (Solomon, 2001).

Apart from the students, the Nigerian Labour congress (NLC) was also against government granting of autonomy to universities as it believed that the programme was being tailored towards the monetization of education, there by making it an elitist venture. Even, the Academic Staff Union of Universities (ASUU) was not left out in the groups of those who initially misconstrued federal government conception of university autonomy. It initial conception was that the issue would result to decentralization of unionism. Thus, it may mean that each university will take care of the welfare of their staff, which many universities would not be able to cope with.

From the federal government perspective, university autonomy does not mean the same thing as government handing off the funding of the universities. Rather, as noted above, it is meant to enable the universities to have the freehand to choose their Vice-Chancellor as well as make some money by the side to augment the federal government funds. According to Obasanjo (2001), University autonomy could enable the institutions to establish and expand its resource base and fashion out an operational level commensurate with its resources limitations without compromising standards of education. Furthermore, each institution should see itself as an entity operating in an environment to which it must tailor its resources and expenditure pattern. As a further elaboration, the granting of autonomy to universities is not intended to mean abdication of government responsibility to fund the universities. Rather autonomy means that the universities will be free from government control, and that the university government council will not only appoint or remove the Vice-Chancellors, but also determine the remuneration package and condition of service of all categories of staff (Onimode, 2000)

\section{UNIVERSITY EDUCATION AND THE PROBLEM OF ACCESS}

The problem of unsatisfied social demand for education has become a polemical issue in Nigeria. As a result of this, two issues are involved in the issue of accessibility. The first one is about the financial ability of the prospective Nigerian students to pay their way through the higher education system. The second issue bothers on the extent to which the academically qualified Nigerians are able to secure admission. These two issues, though socially relevant, are going to be treated with speculation, as the data to evident them are not available.

Meanwhile, Nigerian education is being sponsored with the public funds, except for students in tertiary institutions that were owned by the state government and corporate bodies respectively. The students in the universities owned by federal government do not pay tuition fees and the levies being paid by them for development and administrative purposes were meager. As far as financial accessibility is concerned, it could be argued that prospective students should, despite recession and high incidence of poverty prevalent in Nigeria, be able to attend the tertiary institutions.

Considering the accessibility by academic qualifications, absolute figures of the applicants seeking admission and those offered for a few number of years are being utilized for this purpose. The number of the candidate that register for university education admission when compared to the number of candidate admitted over 
five years, suggests that few were on enrolment due to their inability to meet up with the aptitude test conducted by Joint Admission Matriculation Board (JAMB). This problem of unsatisfied social demand for education is portrayed in table 1 below.

Table 1: Access to University Education in Nigeria (1996 - 2000)

\begin{tabular}{|c|c|c|c|}
\hline Years & Number of Applicants & No. of Candidate Admitted & $\begin{array}{c}\text { Percentage of the Admitted } \\
\text { Candidates }\end{array}$ \\
\hline 1996 & 376,645 & 56,055 & 14.9 \\
\hline 1997 & 419,809 & 73,381 & 17.6 \\
\hline 1998 & 321,368 & 78,550 & 24.4 \\
\hline 1999 & 593,670 & 64,358 & 10.8 \\
\hline 2000 & 467,490 & 50,277 & 10.8 \\
\hline
\end{tabular}

Source: JAMB, Annual Report 1996 - 2000

In Nigeria today, we have 46 Universities; 24 owned by the Federal Government, 16 owned by the State Government and 6 owned by the private corporate bodies. Table 1 above shows that out of 376,645 candidates that applied for University admission in 1996, only 56,055 representing $14.9 \%$ of the total population of the applicants were opportune to be admitted. Also, in the year 1997, a sum total of 419,809 candidates applied for University admission, 73,781 (17.6\%) of them were granted admission. In year 1998, 321,368 candidates applied, 78,550 (24.4\%) of them were granted admission. The year 1999 witnessed a sporadic explosion in the population of the applicants as 593,670 candidates applied for admission, while 64,358 (10.8\%) of them were admitted. In the year 2000, 467,490 candidates applied to the Universities for admission in Nigeria, 50,277 (10.8\%) of them were granted admission.

For the five years examined in the table above, it is evident that application for admission fluctuated from year to year with respect to all components of the institutions. The same fluctuations could be observed with admissions. The second fundamental issues that emerge from the table above is that within five years period, for which data were available, there was never any period that the Nigerian universities admitted up to one quarter of those that applied for admission, the only year that admission seems to be encouraging was in 1998 when admission was offered to about $25 \%$. It appears that this is a trend that lies deep in the past, and the enrolment rates do not reflect better future for the country in terms of manpower needed for socio-economic development in Nigeria. The finding of this paper corroborates Kayode (2000), Ademisokun (1991) and Nuhu (2001) who reported that middle level manpower needs of the country have not always been adequately supplied. They posited further that in view of the gap that may exist in the manpower sector of the economy, the universities should be expanded facility-wise to increase their in-takes, up to, ten-fold.

The problem of inaccessibility of citizens to education is a compounded issue in Nigeria. The efforts of the government and parents toward deregulating education could not yield any fruitful efforts, since majority of the candidates that applied for university education were unable to secure admission into Nigerian universities. Rawl (1993), Mclead (1999) and Alao (1994) contend that unequal access to education either by financial, academic and social standards portend danger in the future socio-economic development of a nation.

In the same vein, Fagbamiye (2000) was of the view that Nigeria's present state of funding education can promote neither equality nor egalitarianism. According to him, the present practice whereby tertiary education enjoys subsidy (tertiary education is more free in Nigeria than primary and secondary education at the present time) than primary and secondary education is inimical to the attainment of the egalitarian goal, since those who cannot afford to attend primary and secondary schools cannot benefit from the virtually free tertiary level of education. Thus, inequalities of access to education can endanger social order in that "Structural inequalities and class relations tend to be inconsistent with the sense of justice of those who are at a disadvantage that is, the subordinate social groups. This perceived injustice would tend to culminate in resentment and conflict in the society (Ninalowo, 1988). 
From the distributive justice point of view, it will be unjust to deny someone access to university education just because he or she could not afford it. The distributive justice emphasizes the aspect of justice, which demands for fair or equitable distribution of the goods, privileges, work and obligations of a society to all the members of the society. Then, if we consider that the functions of university are to preserve, protect, advance and transmit culture, certainly culture is broadly understood to embrace the entire inheritance of knowledge, belief, expectations, moral values, norms and institutions through which humankind becomes civilized and escape barbarism (Gubert, 1994, Omoregbe, 1989, and Olurode, 2001).

Based on the assertion of the scholars above, equality of access to university education becomes a cornerstone of social justice; otherwise, without it masses would be uncivilized. They are not only a danger to themselves but to the civilized society in their immediate environment. In equality of access to university education many slow down the pace of socio-economic development in Nigeria, and even in any other developing nations of the world.

\section{UNIVERSITY EDUCATION, LEADERSHIP AND ETHICAL VALUES/ MORAL INTEGRITY}

The university in Africa and especially in Nigeria is faced with the threat of anomie. This is seen in existence of confusion resulting from intense conflict over norms or even in absence of norms (Appelbaum, 1995). To be more precise, there is a crisis of ethical values in the Nigerian universities. The situation has degenerated to a stage where virtually every cherished principles, moral integrity and ideal of university life has nearly been eroded, if not totally. In some instances, the general norms and ethical values guiding decent and peaceful but harmonious human interpersonal co-existence are absent altogether. Evidence of this can be seen in the high rates of admission racketing, scandals, bribery and graft, victimization, sexual harassment of female students, proliferation of male and female cult gangs, persistent incidence of rape, female prostitution, obscene dressing and soliciting for favours, homosexuality, murder, extortion intimidation of lecturers by students, examination malpractices, rumourmongering and other anti-social activities (Akintayo, 2006). All these immoral, unethical behaviours and attitudes according to Ujomu (2001) serve as indication deteriorating and degeneration of ethical values system that society desire for intense socio-economic development vis-à-vis peaceful co-existence in Nigeria.

In the case of examination malpractices, Goddey (2006) lamented that the situation has degenerated to a stage where students hire other persons who may or may not be students from the same University to write examinations for them. Other illustrations of unethical value system that pervade Nigerian Universities' system is the menace of students' massive involvement in cultism. Several cases of cultic activities of students were reported and published in Nigerian daily newspapers. For instance, some suspected cultists operating within Obafemi Awolowo University at Ile-Ife, Osun State and Olabisi Onabanjo University at Ago-Iwoye, Ogun State in Southwestern Nigeria, killed some students in a deadly assault in 1999 and 2004 respectively.

Moreover, in Southwestern Nigeria, crisis erupted in the University of Ibadan when the university authorities led by Professor Ayodele Falase, the Vice-Chancellor, won a long drawn out legal and moral battle to sanitize the persistently corrupt and misguided students' union leadership which had been involved in a corruption scam involving several hundreds of thousands naira, a local currency. In a wake of the court order to conduct new elections, conflict ensued between the opposing student political groups struggling for control of the students' union organization. The competing political groups freely resorted to violence using guns, charms, knives, and other dangerous weapons in their quest for political supremacy. The situation degenerated to attempt by the struggling group of students to assassinate the Vice-Chancellor. The Vice-Chancellor was nearly kidnapped while his official vehicle was driven away by the unknown arm robbers in the daylight. The University of Ibadan was held hostage for several days by the armed student groups in March, 2001.

Bohme (1999) concludes that, the University in the third world including Nigeria operates in an arena of upheaval and is jested by a world in transition, a world on the border between cultural, technological, social, economic, political and legal environmental changes. These changes had therefore affected the Nigerian universities as one can see the imminent dangers they posed on academic world. This was possible due to inability of the Nigerian populace to adjust to changes in the national and international environments. The University is now faced with the problem of determining the extent to which the enforced and inevitable adaptation to modern times must mean especially on the modification or remuneration of the ever-cherished values and doctrines. 
Besides, the issue of leadership and moral integrity is central to the crisis in the universities in Nigeria. Nigerian university is faced with the situation where those who are in positions of leadership have either abdicated their moral responsibilities. These people have lost the vision of the aims and purpose of their commission, thereby leading to errors and abuses within the university system. This fact supports the assertion of Ritsher (2005) who posited that there has been an alarming lack of responsibility in dealing with the resources of the world. And most especially, we can see that the university, as a key resource or structure for producing human, material capital and wealth, has been guilty of the crime.

\section{CONCLUSION AND RECOMMENDATIONS}

It is evident as portrayed in this paper that university education has remained as pivot upon which the future development of the country rotates in Nigeria. In Nigeria, even though there is unequal access to university education, it would be unfair to insist that the government at all levels have not been concerned about this problem. Efforts have been made towards deregulating and decentralizing university education since 1960s. From 1948 when the University College, Ibadan (now University of Ibadan) was established to date, Nigeria has a total of 45 universities (with 24 federal universities, 15 state universities and 6 private universities). This is an indication of government concern and steps taken towards finding lasting solution to the problem of unsatisfied social demand for university education in Nigeria.

However, there is still room for improvement. The federal, state and local government, as well as, the private organizations should continue to provide moral and financial support to the existing universities. Also, the government of Nigeria should further encourage expansion of the existing universities while government should be establish more technological - based universities to cater for the problem of unsatisfied social demand for higher education and technological advancement in Nigeria. Finally, the government of Nigeria should vigorously enforce the law prohibiting the existence of cultic organizations in order to eradicate cultism among the students in Nigerian universities.

\section{REFERENCES}

1. Abdullahi, F. (2001). University Autonomy's Niggling Doubts. This Day, Tuesday, 14 November, $29-30$.

2. Ademisokun, T. O. (1991). Managing the Nigerian higher Education in Transition, 1945 - 1985: Problems and Challenges in Periods of Uncertainty. In A. O. Sanda (ed.); Understanding Higher Educational Administration in Nigeria, Ibadan: Fact Finders International.

3. Ajani, C. (1999). Higher Education and the Challenges of $21^{\text {st }}$ Century. International Journal of Continuing Education, vol. 2(2), 21 - 33.

4. Ajayi, K. (1999). Quality and Funding of Institutions of Higher Learning in Nigeria. Newsletter of the Social Science Academy of Nigeria (SSAN), Vol. 2(2) September, 19 - 23.

5. Akinkugbe, O. (2001). The Piper, the tune and University Autonomy. Newsletter of the Social Science Academy of Nigeria (SSAN), vol. 4(1), March, $11-15$.

6. Akinpelu, J. A. (2001). Philosophical Imperatives of Higher Education in Nigeria. International Journal Continuing Education, vol. 2(1), 13 - 22

7. Alao, N. (1994). Higher Education: The universities. In O. O. Akinkugbe (ed.); Nigerian and Education: The Challenges Ahead. (Proceedings and Policy Recommendations of the $2^{\text {nd }}$ Obafemi Awolowo Foundation Dialogue, Ibadan Spectrum Books Ltd., 256 - 289.

8. Alumanah, J. N. (2001). Higher Education in Nigeria: Obstacles and Options for Sustainability. In Layi Erinosho, R. A. Akindele, I. N. Obasi and G. J. Odepe (eds.) (2001); Paths to the Sustainability of Higher Education in Nigeria, Proceedings of the $12^{\text {th }}$ General Assembly of SSAN, $37-45$.

9. Appelbaum, R. and Chambliss, W. (1995). Sociology, New York: Harper Collins.

10. Asobie, A. (1998). The Challenges of Political Leadership in Contemporary Nigeria. Committee for the Defence of Human Rights (ed.): Nigerian Students and the Challenges of Leadership, Lagos: CDHR Publication.

11. Banjo, A. O. (1999). The future of Scholarship in Nigeria. Newsletter of the Social Science Academic of Nigeria (SSAN), Vol. 2(1) March, 2 - 11. 
12. Birma, O. (1998). University Leadership in Democratization Process. Journal of Higher Education, vol. 4(2), $17-28$.

13. Bohme, G. (1999). On Educational Problems of Third World. Education, Vol. 20(2), 30 - 38.

14. Committee of Defence of Human Right (2001). Nigerian Students and the Challenges of Leadership. Lagos: CDHR Publications.

15. Engels, F. (1969). The condition of the working class in England. London: Granada Publishing Ltd.

16. Fagbamiye, E. O. (2000). Equality or Egalitarianism in Nigerian Education: Critical Issues. In Aloy Ejiogu and Alani R. A. (eds.); Emergent Issues in Nigerian Education, Vol. 3, Lagos: Mukugamu Nig. Ltd.

17. Girdhood, A. (1995). Evolving roles and responsibilities: The University in Africa. In T. Schuller (ed.); The Changing University, Buckingham: The Open University.

18. Hannah, R. (1998). Merging the Intellectual and Technical Infrastructures in Higher Education: The Internet Example. The Internet and Higher Education, vol. 1(1) 14-22.

19. Kayode, A. (2000). Managing Change in a Nigerian University Setting: The Ibadan Experiment. Ibadan: University of Ibadan Press.

20. Mclead, M. P. (1999). Education, Social Justice and Crisis. Canadian Journal of Education, 9(3).

21. Middlehurst, R. (1995). Changing Leadership in Universities. In T. Schuller (ed.); The Changing University, Buckingham: The Open University.

22. National Policy on Education (1989). Revised Edition. Lagos: NERDC Press.

23. National Policy on Education in Nigeria (2002). Revised Edition. Lagos: NERDC Press.

24. Ninalowo, B. (1998). Education and Society: The Nigerian Case. In P. O. Olusanya and Lai Olurode (eds.); Higher Education in Nigeria, Lagos: John West Publications Ltd.

25. Njomu, P. O. (2001). Leadership, Ethical Values, and Consolidation of Educational Goals in a Nigerian University. Proceedings of the $12^{\text {th }}$ General Assembly of the Social Science Academy of Nigeria, July 3 $7,53-67$.

26. Nuhu, Y. (2001). Higher Education in Nigeria in Perspective. Proceedings of the $12^{\text {th }}$ General Assembly of the Social Science Academy of Nigeria, July 3-7, $12-20$.

27. Nwaka, G. I. (2000). Higher Education, Social Sciences and National Development in Nigeria. Newsletter of the Social Science Academy of Nigeria (SSAN), vol. 3(1) March, 25 - 33.

28. Obasanjo, O. (2004). Leadership and University Autonomy. Nigerian Tribute, Tuesday, February 6, 2 -3.

29. Obembe, J. J. (2001). University Education: Problems and Prospects. Journal of Economic Management, vol. 2(2), October, $109-126$.

30. Olurode, L. (2001). Democratic Imperative and Higher Education in Nigeria: The Quest for Social Justice. In Layi Erinosho, R. O. Akindele, I, N. Obasi and G. J. Odepe (eds.) (2000); Paths to the Sustainability of Higher Education in Nigeria, Proceedings of the $12^{\text {th }}$ General Assembly of SSAN, $29-36$.

31. Omoregbe, J. I. (1989). Ethics: A Systematic and historical Study. Lagos: CEPCO Communication Systems Ltd.

32. Omoregie, P. O. (1994). University funding reflections on budgeting process: University Autonomy, Accountability and University Governance in Nigeria. Proceedings of the $8^{\text {th }}$ General Assembly of the Social Science Council of Nigeria (SSCN), Ibadan, 36 - 43.

33. Onimode, B. (2000). The Funding of Higher Education in Nigeria. Paper presented at the $10^{\text {th }}$ General Assembly of the SSCN on Social Science Research and Public Policy in Nigeria, 4 - 6, December.

34. Plessuer, H. (1992). The University and Adult Education. Education, vol. 30(1), 21 - 33.

35. Ritsher, H. (2005). Education, culture and responsibility. Education, Vol. 30(1), 11-21

36. Rohrs, H. (1989). The Idea of the University in the Contemporary World. Education, vol. 39(1), 20 - 29.

37. Salter, B. (1983). The University Institution in a Changing World. Education, vol. 28.

38. Schuler, T. (1995). The Changing University. Buckingham: The Open University.

39. Solomon, B. (2001). Perspectives on University Autonomy and the Sustainability of Higher Education in Nigeria. Proceedings of the $12^{\text {th }}$ General Assembly of Social Science Academy of Nigeria, July $3-7,21-$ 28.

40. Thompson, A. N. (1981). Education in Africa. London: Macmillan Ltd.

41. World Bank (1994). Higher Education: The Lessons of Experience. Washington: The World Bank. 